\title{
Receiving news from the seat of war: Dublin audiences respond to Boer war entertainments
}

\author{
Denis Condon* \\ School of English, Media and Theatre Studies. National University of Ireland, \\ Maynooth, Ireland \\ The Boer war and its popular representations were uniquely contentious in Ireland. \\ On the one hand, Ireland was a part of the United Kingdom, one of the home \\ countries' of the British empire, with a population that contributed significantly to \\ the imperial project, most prominently represented in relation to the Boer war by \\ Lord Roberts, commander of British forces in South Africa in 1900. On the other \\ hand, the majority of the Irish population supported a nationalist politics whose \\ chief aim at the turn of the century was to gain 'home rule' for the country and \\ which saw the war against the South African republics as another instance of British \\ aggression against a small population determined to assert its independence. This \\ led to a pro-Boer fever among a nationalist population that was ill disposed to the \\ jingoistic pro-war sentiments expressed in much of popular culture coming from \\ Britain. Boer war entertainments in Dublin were frequently contentious, prompting \\ reflection on the possible ideological uses of new media forms.
}

Keywords: Boer war films; audiences; nationalism; unionism; Dublin; Ireland; South Africa

\section{Introduction}

The Superintendents of the "B" and "G" Divisions called on Mr Patterson the manager of the "Daily Independent" and pointed out to him the probability of serious rioting if he perseveres in his Magic Lantern display. They told him that in the event of rioting he might be incriminated as the Magic Lantern display should be regarded as the primary cause.

He received them very civilly, and said he was very much alarmed last evening, that his Directors would meet at $20^{\circ}$ clock and that he would place the matter before them and recommend that the display be discontinued, and that on this night the only thing that would appear, would be an announcement that in deference to public order the Magic lantern would be discontinued. (CBS/1899/20225A/S)

Dated 20 October 1899, this official report by John J. Jones, chief commissioner of the Dublin Metropolitan Police (DMP), to the Undersecretary for Ireland indicates something of the uniquely contentious responses of Irish audiences to popular representations of the second Anglo-Boer war of 1899-1902. Since 13 October, the moderate nationalist Irish Daily Independent had been using a magic lantern to project on a wall of its offices in central Dublin war telegrams and images that included the Boer

\footnotetext{
*Email: Denis.j.condon@nuim.ie

ISSN 1746-0654 print ISSN 1746-0662 online

O 2011 Taylor \& Francis.

DOI: $10.1080 / 17460654.2011 .571034$

http:/wwwinformaworld.com
} 


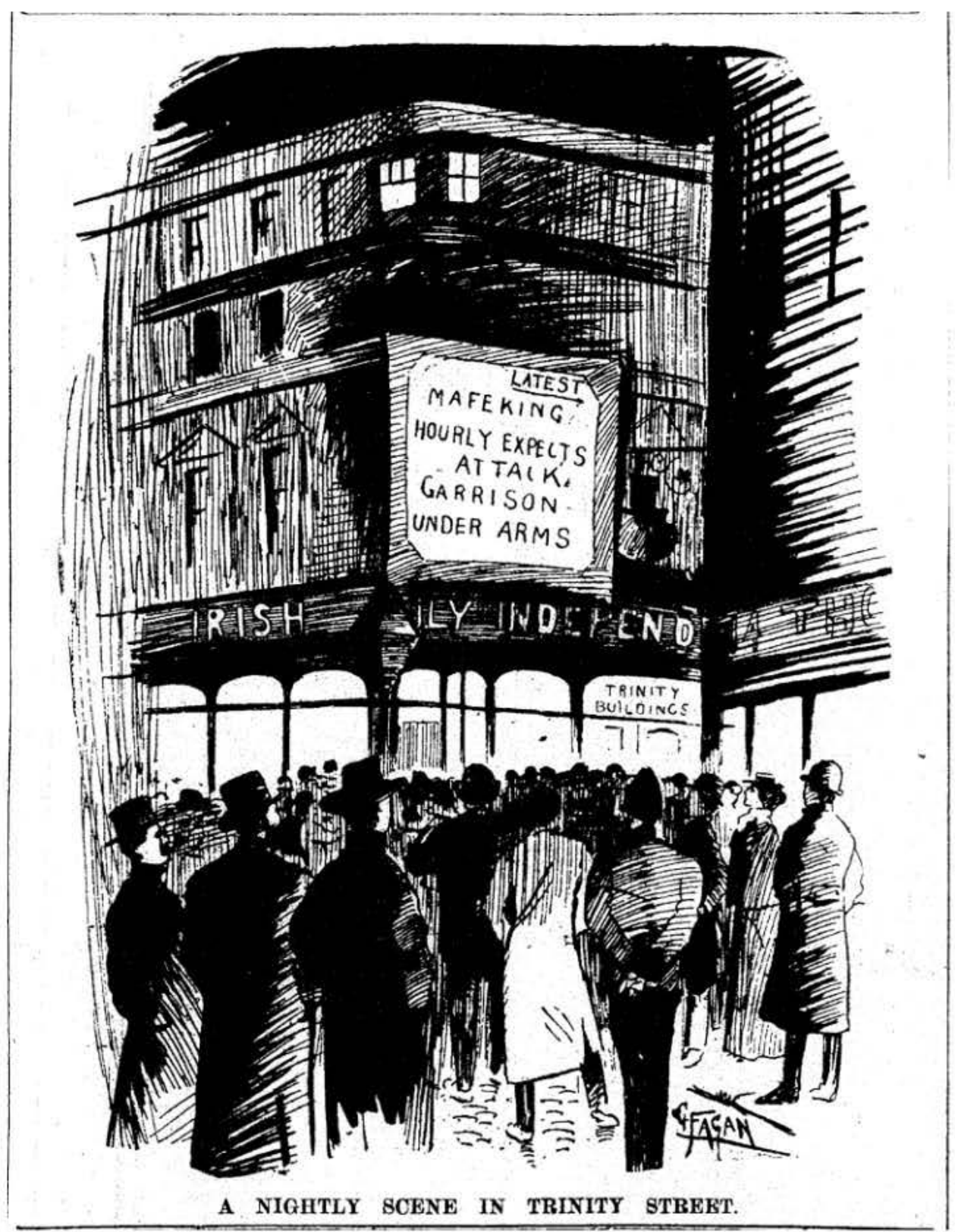

Figure 1. Spectators watch for news of the Boer war projected by magic lantern onto the offices of the Irish Daily Independent. Courtesy of National Library of Ireland.

leaders and the sites of the famous British defeats of Laing's Nek and Majuba Hill during the first Anglo-Boer war (1880-1) (Figure 1). Although the use by newspapers of projected images to draw a crowd has been noted by other scholars (Lacasse 2010), this instance of the provocative juxtaposition of projected news and historical images of the war by a daily newspaper, the paper's promotion of the display in its own pages, and the differing responses of members of the Dublin public that prompted police 
intervention provide an early indication of how a complex interweaving of established and new media forms would be used to represent the war and inflect local interpretations of it.

Given that the magic lantern display was already a part of nineteenth-century visual culture, arguments about the novel experiences of the Boer war that new media forms introduced to turn-of-the-century popular culture have been made particularly in relation to the advent of moving pictures in Britain. "The war itself straddled the end of the old and the beginning of the new century, and marked the end of a tradition dominated by the manual transcription of information and impressions', writes Simon Popple; "New media based on the technologies of the camera and the telegraph altered not only the speed with which the war could be covered but also the nature of the representation' (Popple 2002: 13-14). However, the speeds of photographic and telegraphic transmission were not yet synchronous. Although the realistic and dramatic possibilities of moving pictures would make them an important part of the mediation of the Boer war as it progressed, it would not have been possible for the Independent to show still or moving images of the war itself so soon after its beginning. The long build-up to the war made it possible for film production companies to have camera operators in South Africa, but the speed with which images of the war could appear on screens in Britain and Ireland was, in addition to the difficulties of filming a guerrilla war, dependent on the two-week voyage that it took to ship films from what was often called 'the seat of war'. The telegraph, by contrast, although it could not transmit photographs, could relay information extremely quickly between the parts of the empire suitably connected. So, although war subjects were included on the programme of films being shown by the cineograph projector at Dublin's Lyric Theatre of Varieties in the week following the outbreak of hostilities, these films were from the Spanish-American war, which had been underway for nearly a year and a half. When the advertisement for the turn claimed that 'All Important News from the Seat of War arriving during the Performance will be Announced Nightly on the Cineograph' (Evening Telegraph, 17 October 1899: 1), however, the war referred to was the one in South Africa, and war telegrams were projected by magic lantern in a similar manner to the display at the Independent at the same time. Reviews of the Lyric shows do not mention the telegrams, but one notice suggests that Irish music hall audiences had an appetite for war scenes and, significantly given the later range of contentious reactions to British patriotic imagery, reacted positively to a film show designed to invoke US patriotism:

[T] he audience were treated to a moving representation of incidents in the late SpanishAmerican war, appropriately introduced by "Yankee Doodle" from the orchestra. The pictures were extremely vivid, and in the views which showed a bit of the fight for San Juan Hill there were some situations which roused the audience to an unusual pitch of enthusiasm. (Freeman's Journal, 17 October 1899: 6)

The interchange between these two media contexts of newspaper and theatre recalls Ian Christie's argument that the 'new media' of photographic illustration, telegraphy and film were at the time of the Boer war 'finding their place amid the established media of print and performance' (Christie 2008: 90). Concerned like Popple with the place of moving pictures in the contemporary mediascape, Christie argues that film historians ought not assert the simple novelty of the medium but should instead show 'how film borrowed from and echoed the themes expressed in other media, and how in doing so it negotiated its place in the hierarchy of media consumption - and thus 
contributed to popular sentiment' (Christie 2008: 90). These points are also, of course, relevant to discussion of Boer war entertainments in Ireland, but the British and Irish contexts differed markedly. Most crucially, Irish popular nationalism defined itself against the kind of British popular nationalism examined by Popple and Christie. Furthermore, while British filmmakers produced films designed to appeal to the patriotism of British audiences - and exhibitors enhanced these features in performance few Boer war subjects were produced in Ireland, and jingoistic display elicited strong expressions of disfavour from many Irish audiences.

Nevertheless, Irish nationalism represented only a majority and not all of the Irish population, and other factors relating to Ireland's colonial status complicated how a particular audience might respond to overt celebrations of Britishness. Irish opinions on the war and its portrayals in both established and new media forms map quite closely onto the country's political divisions based on class and religion. The social elite in Ireland were still largely Protestant at the turn of the century, but outside the north-eastern corner of Ireland - where a large Protestant working class supported the union with Britain and greeted Boer war pictures with displays of loyalty - the small-farming and urban working and lower-middle classes were predominantly Catholic and nationalist. This resulted, in the case of Boer war magic lantern shows in provincial Ireland, in what Niamh McCole (2007: 254) calls a clear 'binarism of response' that ranged from the enthusiasm of unionist members of an audience to the demonstrations and 'clever remarks' of nationalist ones. McCole stresses, however, the role of the lecturer in mediating the content of the slides and mitigating negative audience reaction, a factor that would also be crucial in the exhibition of entertainments with moving pictures (McCole 2007: 254-6). As well as this, loyalty to relatives or a prominent member of the local gentry giving distinguished service in the British army often affected local reception in a way that disrupted these ideologically determined responses. The nature of the venue at which Boer war entertainments were exhibited was also of importance, making a rural hall with a small and ideologically uniform audience less likely to create an uproar at an entertainment than a large audience of mixed allegiances in a citycentre theatre with a strong working-class cohort unlikely to be silenced by the protocols of respectability.

\section{Print and performance in the politics of Irish Boer fever}

Despite such factors, the popular audience was overwhelmingly pro-Boer, and responses to Boer war entertainments using moving pictures in Ireland fall within existing ideological constellations in a media hierarchy dominated by press interpretations of the performances of political actors. No ideologically neutral newspapers existed in Ireland. The Irish nationalist press, represented by such titles as the Independent and the Freeman's Journal, faced not only the freely available British press but also the Irish unionist press, represented most importantly by the Irish Times. The Irish nationalist press saw itself in a media war with the British and Irish unionist press over interpretations of the conflict, particularly the latter's minimizing of British losses in late 1899 and early 1900. Although the war was unpopular in many places outside the British empire (Wilson 2001: passim), Ireland's constitutional status as part of the United Kingdom of Great Britain and Ireland, and therefore one of the 'home' countries of the empire, made the Boer fever that raged among the majority of its population unusual - even treasonous - contrasting markedly with the war fever 
that dominated popular responses to the conflict in Britain. Although it seems they fought each other more fiercely than they did for the cause of Irish freedom, all factions of Irish nationalist politics in 1899 praised the Boer determination to protect their independent republics from the depredations of British imperialists intent on using overwhelming force to secure the mineral wealth of the Transvaal. The politics of Irish nationalist Boer fever manifested itself particularly clearly on three fronts: in Westminster, in South Africa, and in Ireland.

In Westminster, nationalist MPs - who held more than three-quarters of the 103 Irish seats - consistently opposed the Conservative government's policy and the Liberal's silence on the war. At the climax of a fiery speech condemning British imperialism, Michael Davitt, MP for Mayo, announced his resignation from the Commons, and travelled to South Africa, where he moved freely in Boer society, covering the war for the Irish nationalist press and writing his 600-page account of the war, The Boer fight for freedom (Davitt 1902). Davitt was the most radical of the Irish MPs, but his views on the war were widely shared by his colleagues. The Irish pro-Boer campaign in parliament alienated Irish MPs from the Liberals with whom they had allied themselves in pursuit of their goal of home rule - limited legislative independence - for Ireland. In the 'khaki' election of 1900 , the Liberals did not want to be associated with the Irish, and removed home rule from their list of objectives (McCracken 2003: 957). Therefore, the parliamentary campaign should not be seen only as the exploitation of the war as a way of furthering the cause of Ireland, but also shows a wider appreciation of the effects of British imperialism.

The level of Irish military involvement on both sides of the conflict in South Africa also indicates something of the attraction and repulsion of empire for the Irish that would be seen in responses to popular entertainments. More than 30,000 Irishmen fought in one of the 13 Irish infantry battalions, three Irish cavalry regiments and seven Irish militia battalions of the British Army sent to South Africa, and nearly 4,500 of them were counted as casualties (McCracken 2003: 134; Jeffery 2000: 142). Among the leading British soldiers with Irish connections were Field-Marshal Lord Wolseley, Field-Marshal Lord Roberts, and General Sir George White. Facing these were less than 300 men who fought with the Boer commandos as part of two Irish Transvaal Brigades, of whom 31 died. However, this disparity in the numbers of Irishmen on both sides exaggerates the extent to which the numbers constitute a particularly Irish response to the war. Unlike the vast majority of soldiers serving in the British army, those in the Irish Transvaal Brigades made a choice to fight, and so their presence constitutes a conscious political decision. Nonetheless, the Irish who volunteered for service in the British army during the war still outnumbered those with the Boers twenty to one (Jeffery 2000: 146-7).

The presence of so many ordinary Irishmen in the British army placed the mainstream nationalist press in an awkward position. Although these papers took a strong pro-Boer stance that reflected the broad nationalist view that saw a clear analogy between the British threat to the self-determination of the Boers and the Irish, their financial survival was based in part on advertising imperial merchandise, such as the series of war-related advertisements for Ogden's Guinea Gold cigarettes, many of them illustrated with humorously presented British patriotic themes featuring the good Tommy (Figure 2). Such advertisements sometimes appeared alongside articles praising the Irish Transvaal Brigades. Furthermore, they adopted strategies to acknowledge the honourableness of Irish soldiers who were fighting as part of the British army against the Boers. The Evening Telegraph article 'A sensational story: Dublin fusilier's 


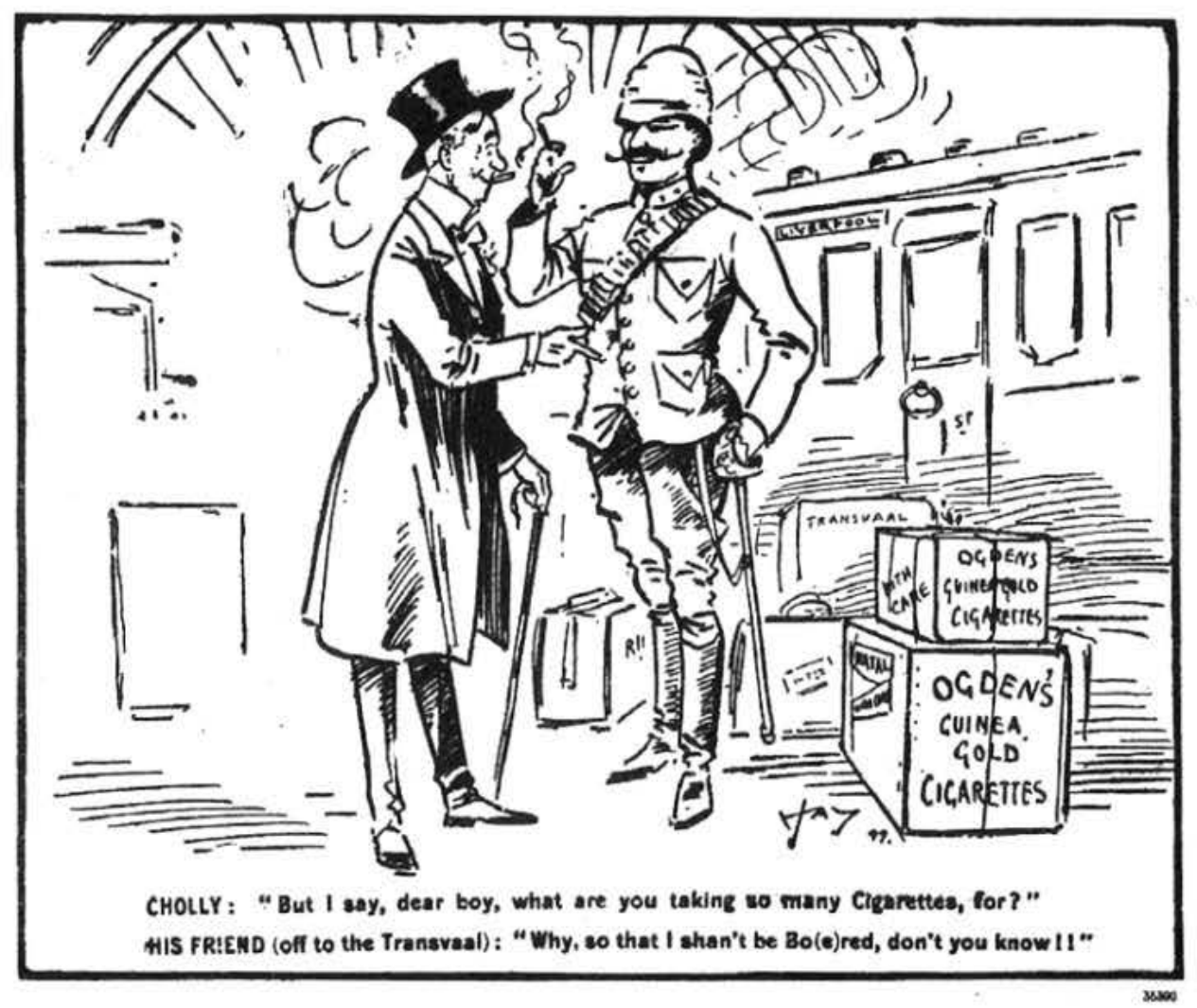

Figure 2. One of a series of Boer war-themed advertisements for Ogden's guinea gold cigarettes that appeared in Irish newspapers. Court esy of National Library of Ireland.

letter from the front: The Boers and the border regiment', for example, presents the soldier's letter home as an alternative source of news from the front and in this case, recuperates members of the British army's Dublin Fusiliers as the ones who tell the true story of British losses covered up by the military hierarchy (27 January 1900: 7).

The existence of Irishmen fighting with the Boers was of enormous propaganda value to the more militant 'advanced' nationalists who organized demonstrations against the war. Prominent among the advanced nationalist press was the United Irishman, edited by Arthur Griffith, who had worked in South Africa and could write about the region with an incisiveness unmatched by any other Irish editor. The uncompromising anti-government and pro-Boer stance of the United Irishman earned it the distinction of being the only newspaper in any part of the United Kingdom to be suppressed for its views on the war (Lowry 2004: 159). Griffith was among the representatives of advanced nationalism who founded the Irish Transvaal Committee. Beginning on 27 August 1899, a month and a half before the outbreak of the war itself, the committee organized street protests in Dublin against imperial oppression of the two South African republics, and these protests received extensive positive coverage not only in the United Irishman but also in the mainstream nationalist papers. It also ran a countrywide poster and leaflet campaign against recruitment to the British army (CBS/1899/20244/S). The pro-Boer demonstrations were eventually proclaimed by 
the Irish authorities beginning with the one due to be held on 17 December 1899, on the eve of the arrival in Dublin of colonial secretary Joseph Chamberlain to receive an honorary degree at Trinity College. When the committee's efforts against recruitment in early 1900 seemed to be having an effect, a two-week royal visit was announced to begin on 3 April 1900. A planned peaceful protest against the Queen's visit was also suppressed by the police (Mathews 2003: 89).

\section{Contentious displays}

The mass demonstrations that convulsed Dublin's public spaces, particularly in the period up to the Queen's visit, provide the context in which such display as the Independent's magic lantern projections should be located. The Independent's management knew they were acting provocatively, and did so in part to win a share of the readership from their larger rival, the Freeman's Journal. 'Serious rioting' was a probable reaction to magic lantern images of the Boer war not because the paper's nationalist readers would seek to show their displeasure at British government policy but because Ireland's pro-war sympathizers, such as unionist Trinity students, were willing to engage in loyal counterdemonstrations. A further elaboration of the events that saw the police visit the editor of the Independent shortly after the outbreak of the war reveals this pattern clearly operating in relation to a display of projected pictures.

At around 8 o'clock on Thursday, 19 October 1899 , between 50 and 100 Trinity students marched from the college's front square to the nearby Independent offices with the intention of 'discourag[ing] the nightly displays of pro-Boer sentiment manifested in Trinity Street' (Irish Dailv Independent [henceforth IDI], 19 October 1899: 6). They were answering the call made on a placard posted in the college some days before calling on students to "come in your thousands and vindicate the honour of your country for true patriotism and loyalty' (Figure 3). Reproducing both the placard and an illustration of a crowd viewing the text of a war telegram projected onto a wall of its offices, the Independent that morning had ridiculed the students' engagement in a 'burlesque war'. 'Alas!' it mocked. 'How many of these brave lads - the scholars of our queen - may leave their bodies in Suffolk or Trinity streets?' The students sang 'God Save the Queen' and other loyal songs as they marched, but when they reached Trinity Street, a strong force of police formed a cordon between them and those who had assembled at the Independent office (IDI, 20 October 1899: 4). This was, according to the police account, 'a mixed crowd' (CBS/1899/20142/S), who had gathered not only for news of the war - which was to be shown later - but also for the results of the final yacht race in the America's Cup. Since early October, the Independent had been displaying coloured lights on the roof of its building indicating the progress of the much-delayed race between the New York Yacht Club's Columbia and the local contender Shamrock, owned by Sir Thomas Lipton of the Belfast Yacht Club. When war broke out on 11 October, the paper had added lights displaying developments in early skirmishes. Although likely made up predominantly of the moderate nationalist readers of the Independent, the crowd was, certainly, mixed in various ways, consisting of those interested in news of the yacht race, those interested in news of the Boers, and those interested in a confrontation with the students. The presence of the latter was encouraged by the fact that the students' poster appeared not only in the Independent but also in the previous day's Evening Herald and on a slide projected at the end of the previous evening's display (IDI, 18 October 1899: 3). Behind the cordon, the students sang and shouted loyal 


\section{WAKE UP TRINITY \\ TO DISCOURAGE TT HE INIGHTLY}

EXHIBITIONS OF PRO-BOER SENTIMENT AMANIESSTED IN TRINITY STREET

SHOW YOUR WORTH

COME IN YOUR THOUSANDS

AND VINDIGATE THE HONOUR, OF YOUR COUNTKY, FOR TRUE PATRIOTISM

$$
\text { AND LOYALTY }
$$

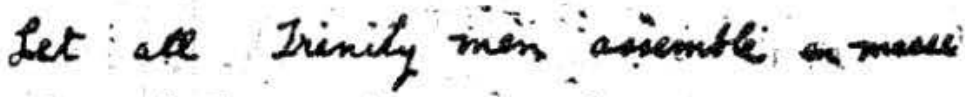
in front square $T C D$ it 8 D.M on THURSOAY, 19\% and suppreas effectuady MO BOER sentimant in DUBLiN Cig GOD SAVE THE
QUE EN

Figure 3. This poster calling loyal Trinity students to action was reproduced in nationalist Evening Herald and Irish Daily Independent and on a slide projected to a nationalist audience assembled outside the Independent offices. Courtesy of National Library of Ireland. 
slogans, but the police eventually escorted them back to the college, pushing them inside the front railings and keeping the demonstrators away. Some stones and other missiles were thrown by the two sides and some windows smashed, but the determination of the police kept the sides apart and prevented serious injury.

In a mocking tone similar to the previous morning's, the Independent report of these events downplayed the threat posed by the effete students to what it presented as its solidly working-class supporters:

Now and then students rushed to the rails and attempted to strike people outside with some sort of trifling looking weapon that would be more appropriate and effective for applying to a refractory schoolboy instead of subduing a hardy son of toil. (IDI, 20 October 1899: 4)

However, Trinity students showed themselves fully capable of initiating violent demonstrations, as they did on the occasion of Chamberlain's visit in December 1899 and on the relief of Mafeking in March 1900, when they paraded through the streets, assaulting several people and stealing the city flag from the Mansion House. At the Independent, the projections and associated demonstrations ceased (CBS/1899/ $20225 \mathrm{~A} / \mathrm{S})$.

\section{Uproar and hideous noises}

Involving as it does a news organization and the official channel of reporting provided by the police, this case offers very detailed sources on the contentious reception in Ireland of publicly projected pictures of the war. Irish audience reactions to Boer war entertainments in the theatres and other ludic spaces were often contentious, dividing the auditorium along nationalist/unionist lines, but these divisions were usually expressed only in such 'audiative' form as cheering, hissing, shouting slogans, groaning and singing patriotic songs (Loiperdinger 2009). Because they did not approach the point of riot and so involve the police, the sources of information on such responses are far less comprehensive than in the case of the Independent's displays, consisting almost exclusively of brief reviews in newspaper and magazines. Nevertheless, a sufficient corpus of such material exists to suggest how Irish audiences responded to the particular aesthetic features of the new moving pictures in mediating the Boer war differently from existing popular forms.

Distinguishing between the reception of different popular forms is both facilitated and made more complex by the fact, as is the case of some of the earliest moving images of the Boer war exhibited in Ireland, that they are usually combined to produce such variety entertainments as the music-hall programme, fairground attractions and the pantomime. In late December 1899, Dublin's Theatre Royal advised patrons that its pantomime Robinson Crusoe would culminate with a 'Grand Bio Tableaux. The Latest Development of the Brilliantly Successful Living Photography, with all the Latest Eventful Pictures' (Irish Playgoer, Vol. 1, Issue 7 [21 December 1899]: 14). On the opening night, the pictures do not seem to have been shown because of the audience reaction to the penultimate spectacle, a well-drilled group of children dressed in Dublin Fusilier uniforms:

The cheers with which the fusiliers were received were completely drowned by a storm of hisses from the popular parts of the house. There were cheers for Kruger, and demands 
to put down the Royal Standard, which was borne aloft by the soldiers. Thus ended what was undoubtedly a sprightly and an amusing representation of a clever and a popular pantomime. (IDI, 27 December 1899: 8)

When the pictures were shown on the second night, a reviewer described them as including such 'displays of British interest' as 'English and Colonia[1] troops, Lord Wolseley inspecting the Roslin Castle', and there were greeted by

the usual mixed demonstration - apparently liked by all theatrical managements provided the demonstration is mixed - followed, just as the appearance of a band of welltrained children attired as Dublin fusiliers had evoked cheering and hissing in the previous scene. (Evening Telegraph, 28 December 1899: 3)

Although the pictures were of actual soldiers rather than children in costume, audiences treated these different representations as serving the same ideological function. The implication that theatre managers actively courted controversy in a similar way to the Independent editors as an acceptable and lucrative exhibition strategy when dealing with ideologically divided audiences is plausible to a certain extent, but it would have had to have been judged carefully to avoid alienating large numbers of patrons. Indeed, other commentators denied that this would be successful with 'ordinary' playgoers. Having noted the hard work of the young performers, a writer for the short-lived Dublin-based theatre journal Irish Playgoer expressed regret that the children's fusilier number

should have met with such a mixed reception. Goodness knows I am as strong anyone on the folly of introducing on Dublin stage any reference to the war, but I cannot for the life of me see why a capital little bit of training of children cannot be exhibited, even in red uniforms as well as in, say cannibal costume, without producing mingled cheers and hisses. (Vol. 1, No. 8 [28 December 1899]: 6)

Although the writers at the Plavgoer were no more immune to the ideological currents of the country than were those at the newspapers, their focus on the theatrical experiences of audiences offers uniquely detailed insight into Irish theatregoing at the turn of the century.

The Plavgoer shows that theatre audiences voiced their displeasure at jingoistic displays by British artistes on the Dublin stage from an early point in the war. In January 1900, the journal's 'Odds and ends' column advised '[t] hat all reference to the war and soldiers should be omitted from our entertainments for the present, seeing the divided state of our people on the matter' (Vol. 1, No. 9 [4 January 1900]: 4). In a February issue, a writer described the mainly middle-class Gaiety Theatre audience as 'over sensitive'. 'Our Wilkie Bard was singing a capital medley song, and the very mention of one line of "The Soldiers of the Queen" created an uproar' (Vol. 1, No. 14 [8 February 1900]: 12). At the same theatre, more substantial disruption greeted the opening of the musical comedy San Tov, which included such jingoistic songs as 'Tommy Atkins' from The gaietv girl. '[T] he indefensible introduction of war glorification', commented a reviewer,

and jingoistic bunkum of that sort completely marred the or dinary playgoer's enjoyment on the opening night, as each reference to such caused a disturbance, which, at times, developed into quite a pandemonium of discordant sounds that completely obliterated what was taking place on the stage. This introduction of contentious matter into musical plays ought to be discontinued, especially in Dublin, where so much diversity of opinion 
on such-like affairs is, at present, or in fact, always to be found. (Irish Playgoer, 3 May 1900: 11)

It was not just the legitimate theatre audience at the Gaiety that reacted in this way. When comic singer Harriet Vernon appeared on stage at the Lyric music hall on 15 May 1900, dressed as an English officer though she looked exceptionally well in the uniform, a very large number of the people who were present objected, and showed that they did so in the usual way'. Despite establishing that the uniform was the problem, "Vernon came out in the same dress and sang what a majority of the audience considered a Jingo song, with the result that during the time she was on the stage hissing was very noticeable' (IDI, 15 May 1900; quoted in Irish Plavgoer, 24 May 1900: 2). Plavgoer columnist Conn comments:

1, for one sincer ely wish the war was over, in order that amusement-seekers in Dublin may again be allowed to enjoy themselves in peace. [...] I fear our local managers are greatly to blame for the state of affairs that exists at present, in not compelling all companies to 'blue pencil' every Jingo allusion while here. [... I] f this were done, I, for one, would go with a merrier heart to the theatre, knowing that I could then sit out a play without uproar and hideous noises. (Ibid.)

While Vernon's decision to retain the jingoistic elements of her performance in spite of audience displeasure appears knowingly provocative, the audience's reaction to moving pictures could be modulated by the way exhibitors presented them. It seems that when the films were presented in a neutral way, without the use of patriotic display in the lecturer's presentation and in the choice of music, they could be accepted as information rather than resisted as propaganda. What appear to be the first Boer war films on the Dublin music-hall stage were exhibited by Scott's metascope, 'the most up-to-date appliance for showing living pictures' (Evening Telepgraph, 10 March 1900:8), at the Lyric in March 1900. As well as views of the battles of Spion Kop, Modder River, and Nicholson Nek mentioned in the advertisement, the show included both general views of South Africa and other war films,

among many others, Cape street, Port Elizabeth; the Roslin Castle, conveying consignments of troops for the war; the "Fighting Fifth" digging trenches at Estcourt; a Skirmish with the artillery outside Ladysmith; the Lancers at the Modder River; Bridging the Tugela, and Watering the Artillery and Transport Mules; the Ambulance at Work, etc. (Ibid.)

Surviving reviews do not mention demonstrations at the exhibitions of these films or at those in the rival Empire Theatre of Varieties just a month later. Reviewing the first week of "WAR PICTURES. The Very Latest, including "Relief of Kimberly," Troops in Action, Most Thrilling Scenes' and the first showing of 'HER MAJESTY THE QUEEN'S Gorgeous Entry into Dublin', the unionist Dublin Evening Mail merely comments that they 'were greatly appreciated' and 'received with unstinted applause' (10 April 1900: 1; 14 April 1900:3).

The first autonomous cinematograph show at which substantial protests are recorded was the Modern Marvel Syndicate's film and variety show at the Rotunda between 8 and 20 April 1901 . The company was run by T.J. West, 'a gentleman long and favourably known in theatrical and amusement matters in Dublin, his association with our city extending over twenty-five years, during which time he has been very successful in his endeavours to meet the public taste' (Evening Telegraph, 13 April 
Vietories by Telegraph.
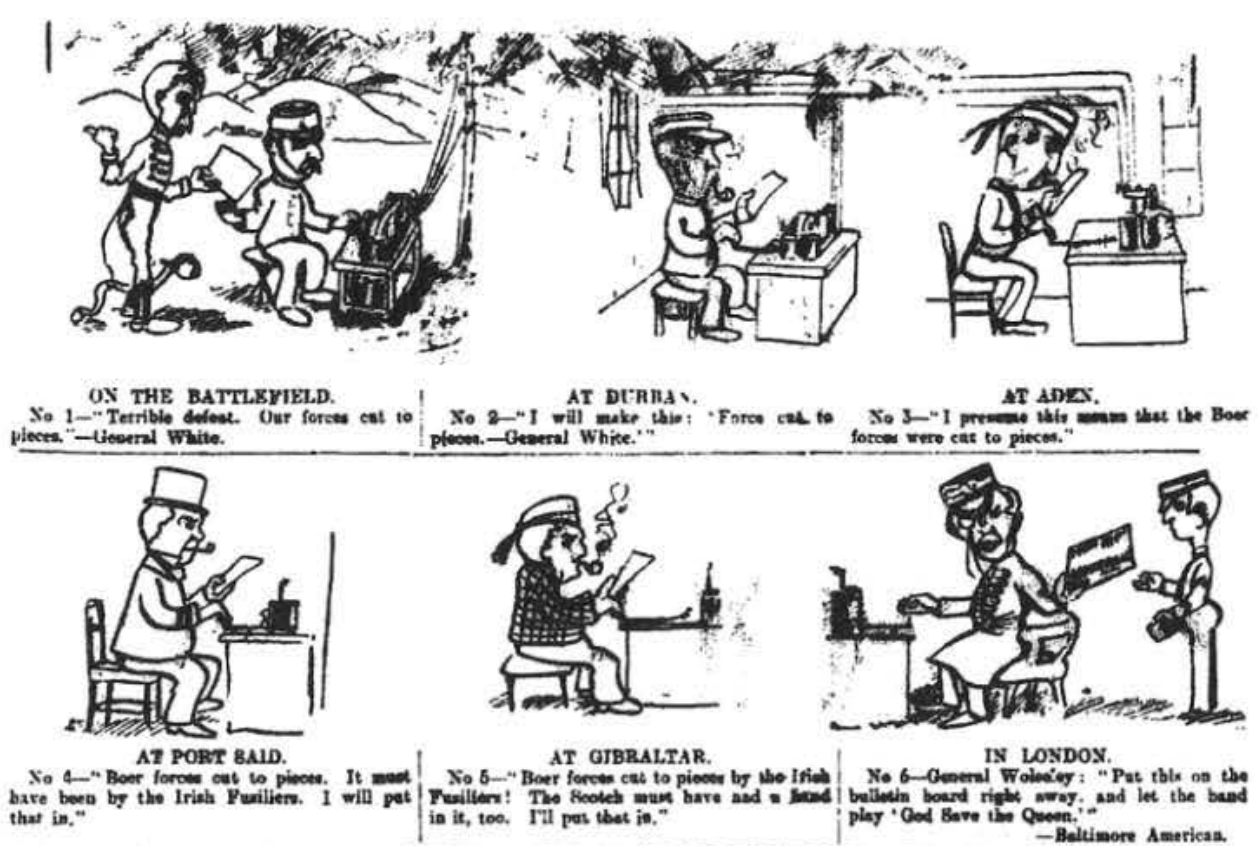

Figure 4. How telegraphy makes news of a British defeat into a celebrated victory, with an Irish telegrapher adding to the error; from Evening Telegraph, 9 December 1899. Courtesy of National Library of Ireland.

1901: 8). Far from offering a damning verdict, the reviews in the Telegraph might be said to be generous in their attentiveness but equivocal in their praise. Their overall assessment is that ' $[\mathrm{t}]$ he whole show certainly makes an amusing, interesting, and wonderful entertainment' (Evening Telegraph, 9 April 1901: 3). The variety acts, consisting of singers and jugglers, were 'a pleasing adjunct to the photographic portion'. This main attraction was two Georges Méliès' fiction films Joan of Arc and The Christmas Dream and 'a series of up-to-date events, all instinct with actual life'. It was certain of these actualities that elicited conflicting responses from the audience:

Some did not meet with the approval of a large section of the audience. They objected to representations of her late Majesty Queen Victoria, and scenes representing 'Our gallant soldiers, who have been fighting for the last eighteen months.' Some of those present cheered and clapped, and the remainder booed and hissed, but probably both parties were satisfied, notwithstanding the Khaki flavour of that portion of the entertainment, for, as a show, it was good, and this, the manager said, was all he wanted the audience to admit. (Ibid).

By the end of the week, the Telegraph was describing the show without mentioning audience disapproval. It seems likely that West altered the show to make it more acceptable to the divided loyalties of Irish audiences.

Two South African-themed entertainments played seasons in Dublin to coincide with the lucrative Horse Show week in late August 1901 demonstrate the benefits of ideological ambiguity. Savage South Africa, playing at the grounds at Jones's Road, 
advertised itself in the week of 29 July as 'NOT A CIRCUS BUT REAL LIFE. NOT PICTURES BUT REALITY' (Evening Telegraph, 29 July 1901: 1). Its demonstrations of trick riding, mock battles and pageantry based on the Zulu wars were lent new currency by the outbreak of the Boer War, and new acts were added accordingly (Popple 2002: 23). 'A detachment of what was described as "genuine Transvaal Boers,", reported the Dublin Evening Mail,

made their appearance, and were naturally the recipients of a mixed reception. [... A]nd the piece de resistance was afforded in the concluding spectacle dealing with the battle of Elandslaagte, in which the rattle of Maxim guns and the roll of heavier ordnance played a leading part. (6 August 1901: 2)

'Mixed reception' here seems to mean that the Irish audience were unsure of how to greet representatives of the Boers rather than that the spectators split on ideological lines. Although its focus on the early British victory at Elandslaagte made the proBritish stance of Savage South Africa clear (Pakenham 1979: 133-41), the reviews suggest that audiences could choose to read this variation on the Wild West show as pro-Boer, pro-British, or apolitical spectacle.

The other South African-themed entertainment running in August was not so ambiguous in its address to its audience. One of the Poole's myriorama companies, which had long-established links to Dublin, encountered difficulty because of the jingoism of its Boer war-based show of panoramas, photographs, moving pictures and varieties. Owned by Joseph Poole and managed by Fred Mayer, the company provided an entertainment

\begin{abstract}
styled 'Our Empire,' and the title is entirely expressive and descriptive. The principal portion consists of scenes in the Boer war, and while the pictures as pictures are good enough, the history pourtrayed $[\ldots]$ by them will not be of much assistance to the young student. Of course the Myriorama was painted for a British audience who imagine that their aggression in the South African Republics has been an uninterrupted series of successes, and that the Yeomanry are the equal of Napoleon's Old Guard. Yesterday these pictures were not received with unmixed approval. (Evening Telegraph, 6 August 1901: 4)
\end{abstract}

The Telegraph reiterated its claim of controversy in its Saturday 'Music and the drama' column at the end of the first week of the season:

Poole's Myriorama cont inues to draw large houses at the Round Room, Rotunda, and the pro-British representation of South African war scenes give rise to a little excitement nightly between the patrons of the show who hold opposite views on the subject of the war. (10 August 1901: 8)

In assessing the entertainment as a whole, the Telegraph reviewer admires the images as aesthetic objects while criticizing the ideological work to which they are put in advancing the British cause against the Boers.

The popular visual culture of the Boer war forced Irish audiences to confront the fact that the new media - although not inherently imperialistic - entered into existing ideologically configurations (Figure 4). Because British companies to a large extent produced and exhibited the moving photographic images and many other popular representations of the war seen by Irish audiences, the likelihood was that they would be located in a strongly pro-empire context. Irish audience came to appreciate that although the new media were remarkable technological achievements, they could be 
made to lie, whether inadvertently, to increase their entertainment value, or to suit the ideological position of the user.

\section{Note on contributor}

Denis Condon lectures on cinema at the School of English, Media and Theatre Studies, NUI Maynooth, where his research and teaching interests include Irish cinema, early cinema and popular culture, Hollywood and documentary. His book Early Irish Cinema, 1895-1921 (Dublin: Irish Academic Press) appeared in 2008.

\section{References}

Christie, 1. 2008. 'An England of our dreams"?: Early patriotic entertainments with film in Britain during the Anglo-Boer war. In Early cinema and the 'national', ed. Richard Abel, Giorgio Bertellini and Rob King, 90-1. New Barnet: John Libbey.

Crime Branch Special Papers (CBS), National Archives of Ireland.

Davitt, M. 1902. The Boer fight for freedom. New York: Funk and Wagnalls.

Jeffery, K. 2000. The Irish soldier in the Boer war. In The Boer war: Direction, experience, and image, ed. J. Gooch, 141-51. London: Frank Cass.

Lacasse, G. 2010. Les 'journaux filmés' entre tradition et nouveauté. Paper delivered at the Domitor conference Beyond the Screen: Institutions, Networks and Publics of Early Cinema, 15 June, at Ryerson University/University of Toronto, Toronto, Canada.

Loiperdinger, M. 2009. Screening the Boer war in Germany: Audience response and censorship. Paper delivered at the Visual Empires conference, 4 July, University of Sheffield, Sheffield, UK.

Lowry, D. 2004. Nationalist and unionist responses to the South African war, 1899-1902. In Newspapers and empire in Ireland and Britain: Reporting the Britishempire, c. 1857-1921, ed. S. Potter, 159-76. Dublin: Four Courts Press.

Mathews, P.J. 2003. Revival: The Abbey Theatre. Sinn Féin, the Gaelic League and the co operative movement. Cork: Cork University Press/Field Day.

McCole, N. 2007. The magic lantern in provincial Ireland, 1896-1906. Early Popular Visual Culture 5 , no. $3,247-62$.

McCracken, D. 2003. Forgotten protest: Ireland and the Anglo Boer war. Belfast: Ulster Historical Foundation.

Pakenham, Thomas. 1979. The Boer war. London: Weidenfeld and Nicolson.

Popple, S. 2002. 'But the khaki-covered camera is the latest thing': The Boer war cinema and visual culture in Britain. In Young and innocent? The cinema in Britain 1896-1930, ed. A. Higson, 13-14. Exeter: University of Exeter Press.

Wilson, K., ed. 2001. The international impact of the Boer war. Chesham: Acumen. 